\title{
Virtual Identity of Hijab Celebrities
}

\author{
Deasy Juliani*, Anne Ratnasari, Ike Junita Triwardhani \\ Faculty of Communication \\ Universitas Islam Bandung \\ Bandung, Indonesia \\ *pandaechie@gmail.com, anneratnasari10@gmail.com, junitatriwardhani@gmail.com
}

\begin{abstract}
The rapid development of information and communication technology leads people to a new world, the virtual world. Just like the real world, in the virtual world, every individual has an identity that they want to appear in cyberspace, either through photos or videos. One of them is on Instagram social media. Someone's identity on Instagram social media can be the same as real identity in the real world or different. The method used in this research is a qualitative method with a phenomenological approach. The informants of this study were five of the hijab celebrities in Bandung and five supporting informants. Data collection techniques in this study is conducted by in-depth interviews and documentation. The results of this study indicate that the hijab celebrities in Bandung have a virtual identity that remains the same as real life, some that are different from real life, while the front virtual, middle virtual and back virtual produce typifications; religious hijab celebrities, endorse hijab celebgram, and trendsetter hijab celebgram.
\end{abstract}

\section{Keywords—virtual identity, fenomenology, hijab celebrity}

\section{INTRODUCTION}

Instagram as a social media with this multimedia genre is a place to form a visualization of someone with all their activities. Media like this can form and build opinions by means of good and appropriate visualization. In other words, Instagram facilitates someone "to be who you want to be" and "to be like what you want to be" in the virtual world. However, not only as a personal representation, personal branding, or a medium of communication, an Instagram account is even seen as no longer representing ourselves in the real world.

This is what happened to the hijab Instagram celebrity or hijab celebgram they called. Hijab celebrities are those who have hundreds to million followers on Instagram [1]. They present a variety of content, such as travel, make-up, and fashion. Not only that, they also come from various backgrounds, ranging from entrepreneurs, housewives, and freelancers.

Their presence is considered capable of communicating pious and contemporary Muslim women who follow trends. Yet if you look at the legal basis regarding the obligation of Muslim women to wear hijab, in the Al-quran it is clear that Allah SWT ordered the Prophet Muhammad SAW to call for the obligation to cover aurat for a Muslimah [2]. This condition is different from the image of Muslim women in the past, where Muslim women have limitations in expressing themselves, both in their environment and in the media [3]. It is not uncommon for comments from followers to show statements of disagreement with the content uploaded by the hijab celebrities. Also, negative comments emerged.

Without realizing it, Instagram forms a person's character and identity in it. Instagram as a self-presentation channel for users provides unlimited space for each individual to present himself. Users have the widest freedom to communicate. Instagram also encourages its users to actively participate in constructing their own identity [4].

Muslim women represented through the hijab celebrities gave birth to a discourse on the beauty of new Muslim women. Where beautiful, not only spiritual beauty, but also strengthened by physical beauty [5]. From the results of research conducted by Fardiana, the beauty represented by the hijab celebgram is classified into 3 (three) major concepts. First, spiritual beauty or inner beauty which consists of religious beauty, calming, and fun. Second, ethical beauty or inner outer beauty, which consists of feminine beauty, "free" beauty, and respectful beauty. Third, physical beauty or outer beauty, which consists of beauty that shows luxury and the care and use of makeup. In this third concept, beauty is accompanied by the use of luxury items and body care and the use of makeup. Many hijab celebrities use excessive make up. Contrast when associated with Islamic teachings that advocate simplicity, including simple make-up [5].

When someone needs information, they will come to a reliable source. With the condition of the people who now spend a lot of time looking for information online, this is the reason why Instagram celebrities (celebgram) are one of the professions that are taken into account [6]. Even data from LinkedIn states that during the years 2005-2015, the average number of jobs for journalists and public relations has decreased by $14 \%$. Their role was replaced by influencers (content creators, celebrities, social media analyzers), which increased by $30 \%$ [6].

Based on this explanation, it is necessary to conduct research on the virtual identity of hijab celebrities. This study aims to determine the virtual identity of hijab celebrities and to identify the front virtual, middle virtual, and back virtual hijab 
celebrities that form their self-concept in the virtual world. This research is expected to be a consideration for users of the hijab celebrity, both the government or other institutions in choosing the hijab celebrity to promote the brand or product that is being promoted according to its segment.

\section{METHODS}

This study uses a qualitative research method with a phenomenological approach. Researchers assess qualitative research as the most suitable method because it is carried out in natural conditions (currently occurring) and the results cannot be described by statistical procedures or other quantitative methods [7]. Researchers also assessed the research method used as relevant to the phenomenological approach because from the point of view of qualitative research, reality is socially constructed based on joint decisions [8] and no less important relevant to understanding the phenomena of what is experienced in the research subject [9].

The phenomenological approach according to Moustakas [10] is seen as a research strategy in which researchers identify the nature of human experience about certain phenomena. The focus of this approach is to explore and understand the meaning that is built on the reality of human life from everyday life [11]. In each procedure, researchers must examine many of subjects by being directly involved in them to develop patterns and meaning relationships.

Understanding the experience of human life, making phenomenology an approach, each procedure makes researchers have to study some of subjects by being involved in them to develop patterns and meaning relations.

The data obtained from this study are the results of in-depth interviews with five hijab celebrities obtained using a purposive sampling method. Where the researcher determines who the key informants for research are based on the criteria made by the researcher Sugiyono [7]. These criteria include; hijab celebrities, aged 15-34 years, have more than 10,000 followers, and are specialized in content. The key informants in this study were 5 (five) hijab celebrities such as; Bella Attamimi, Ghaida Tsurayya, Sonya Fatmala, Asri Ismaya, and Rissa Stellar. For the research results to be unbiased, the researcher triangulated the source by interviewing five additional informants, namely the followers of each hijab celebrities.

\section{RESULTS AND DISCUSSION}

\section{A. Hijab Celebrity Virtual Identity}

Identity is not generated by itself but the result of interactions with other people. Identity can also be negotiated, strengthened, and even changed in a communication process [12]. However, in the context of the virtual world, Andrew Wood and Matthew Smith have different opinions about the identity that applies on the internet.
Wood and Smith state that this virtual identity is so complex, it includes what we think about ourselves and how other people see us [13]. So, self-performance is an individual effort to construct him/herself in an online context through photos, videos or writing so that the social environment is willing to accept the existence and have the same perception as the individual.

Wood and Smith divides three types of individuals in the virtual world, including [13]; real life identity is an identity that shows who the individual really is, pseudonymity is a real identity that starts to blur even becomes fake in the virtual world, and anonymity is an identity that is completely separate and cannot be referred to who the identity is as can be seen in table 1 .

TABLE I. REAL LIFE IDENTITY AND HIJAB CELEBRITY VIRTUAL IDENTITY

\begin{tabular}{|l|l|l|l|}
\hline No. & \multicolumn{1}{|c|}{$\begin{array}{c}\text { Informants' } \\
\text { Name }\end{array}$} & Real life identity & Virtual identity \\
\hline 1 & Bella Attamimi & $\begin{array}{l}\text { Good } \\
\text { personality, feel } \\
\text { talkative, } \\
\text { uncomfotable } \\
\text { with new people }\end{array}$ & $\begin{array}{l}\text { Expert in hijab } \\
\text { travel, calm and } \\
\text { friendly person }\end{array}$ \\
\hline 2 & Ghaida Tsurayya & $\begin{array}{l}\text { Religious, good } \\
\text { person, friendly, } \\
\text { and modest }\end{array}$ & $\begin{array}{l}\text { Religious, } \\
\text { friendly and } \\
\text { modest }\end{array}$ \\
\hline 3 & Sonya Fatmala & $\begin{array}{l}\text { A kind, friendly, } \\
\text { and outgoing } \\
\text { person }\end{array}$ & $\begin{array}{l}\text { Always sharing } \\
\text { parenting } \\
\text { knowledge, good } \\
\text { personality, } \\
\text { always happy, } \\
\text { generous }\end{array}$ \\
\hline 4 & Asri Ismaya & $\begin{array}{l}\text { Good personal, } \\
\text { friendly and fun }\end{array}$ & $\begin{array}{l}\text { Expert in fashion } \\
\text { good person, } \\
\text { modest, and not } \\
\text { adventurous }\end{array}$ \\
\hline 5 & Rissa Stellar & $\begin{array}{l}\text { A kind and quiet } \\
\text { person }\end{array}$ & $\begin{array}{l}\text { Lipstick expert } \\
\text { and unfriendly } \\
\text { personal }\end{array}$ \\
\hline
\end{tabular}

The real-life identity is shown by the informant Ghaida Tsurayya. In the virtual world, informant Ghaida Tsurayya always reminds her followers through Al-quran verses or hadiths which she makes as captions in each of her content (interview with Ghaida, 18 December 2019). In real life, informant Ghaida Tsurayya is also a religious person. In every conversation, she always associates it with hadiths or quotes from the Al-quran verse (interview with Ghaida, 18 December 2019).

As well as informant Ghaida Tsurayya, informant Asri Ismaya also showed real life identity. In the virtual world, informant Asri Ismaya is a person who does not want to show that she is a hijab celebrity and does not want to be judged as a fake (interview with Asri Ismaya, 10 January 2020). Her figure is friendly and cheerful just like the display she constructs on Instagram. She wants her followers to see her as a friendly person (interview with Asri Ismaya, 10 January 2020). 
The pseudonymity was indicated by informant Rissa Stellar. In the virtual world, Rissa shows herself as the first lips watcher in Indonesia who really talks about lipstick. Virtual, $100 \%$ talks about lipstick, uploads about personal things, she only occasionally displays on her Instagram (interview with Rissa, January 17, 2020). In real life, informant Rissa is an introvert, especially about personal life. She is more enthusiastic when talking about lipstick (interview with Rissa, January 17, 2020). In terms of personality, informant Rissa Stellar is considered as her followers, judging that the virtual language of informant Rissa in replying to comments on Instagram shows that she is not a friendly person (interview with Annisa Rilia, followers of Rissa, January 23, 2020).

Pseudonymity in virtual life was also shown by informant Bella Attamimi. In the virtual world, she has constructed herself as a hijab celebrity who likes traveling, fashionable and wise. The content displayed is about mix and match hijab when traveling through the outfit of the day (OOTD) (interview with Bella, 29 November 2019). 95\% of informant Bella Attamimi's virtual views show "work" as a hijab celebrity, while personal content is not displayed (interview with Bella, 29 November 2019). In real life, informant Bella Attamimi is considered to be a friendly and pleasant person even with people she just met (Bella's interview, 29 November 2019).

Informant Sonya Fatmala also shows pseudonymity in her virtual life. In a virtual world, informant Sonya has constructed herself as a good mother, has a happy family, friendly, and always shows positive things in every post. The virtual identity she created aims to attract the attention of endorsers to use her services according to the figure she displays in her virtual world (interview with Sonya, January 5, 2020). Even though she limits her personal life, she displays a friendly personality both in her virtual life and in real life (interview with Sonya, 5 January 2020).

\section{B. Front Virtual, Middle Virtual, and Back Virtual of Hijab Celebrity}

If we interact face-to-face, we can understand someone's identity through speech, clothing, or other non-verbal characteristics. However, it is not that easy to understand a person's character through the virtual. This is because communication carried out face to face has turned into account to account [14]. It is not impossible, if a person does not want to show her true self in her virtual world [15].

This idea is likened to Goffman, a performance stage known as impression management, "The individual will have to act so that she intentionally or unintentionally expresses himself and the others will in turn have to be impressed in some way by him" [16]. So, each individual always acts intentionally or unintentionally to express himself and others will be impressed by the way or expression of each individual. Like a show, there are those called the front stage, middle stage, and back stage [16].
In analyzing the virtual identity of the hijab celebrity, the researcher used different terms from the front stage, middle stage and back stage as Goffman's idea. Researchers replace other terms that are relevant to the research results, namely front virtual, middle virtual, and back virtual. Although similar, impression management has a broader scope. There is a process of internalization or interaction that ultimately results in the front stage, middle stage, and back stage. However, in this study, virtual identity shows what key informants show in their virtual world only. Everything is purely from within the key informant without any interaction.

The virtual front is where the hijab celebrities display a performance that is admired by their followers. Middle virtual is another virtual outside the front virtual as hijab celebrities communicate messages through the virtual front. Back virtual is an area where the individual shows himself according to the original character without having to worry about anyone paying attention. Back virtual shows the real life of the key informant. Usually, moments in back virtual are rarely uploaded to their virtual front (see in table 2).

TABLE II. Front VIRTUAL, MidDle ViRTUAL, AND ViRTUAL OF HiJAB CELEBRITY

\begin{tabular}{|c|c|c|c|}
\hline \multirow{2}{*}{ No } & \multicolumn{3}{|c|}{ Informan 1 : Bella Attamimi } \\
\hline & Front virtual & Middle Virtual & Back Virtual \\
\hline 1 & Hijab Celebrity & $\begin{array}{l}\text { Using instagram } \\
\text { application }\end{array}$ & Freelancer \\
\hline 2 & $\begin{array}{l}\text { Fashionable with } \\
\text { hijab and match } \\
\text { color outfit }\end{array}$ & $\begin{array}{l}\text { Preparing outfit } \\
\text { and hijab for mix } \\
\text { and match }\end{array}$ & $\begin{array}{l}\text { Appear to be } \\
\text { modest and simple } \\
\text { outfit, mostly wear } \\
\text { sandal when go } \\
\text { outside }\end{array}$ \\
\hline 3 & Simple make up & $\begin{array}{l}\text { Wear cushion, } \\
\text { blush on, mascara, } \\
\text { and lipstick }\end{array}$ & Without make up \\
\hline 4 & $\begin{array}{l}\text { Posts caption appear } \\
\text { to show cool and } \\
\text { wise personality }\end{array}$ & $\begin{array}{l}\text { Compose the } \\
\text { words to be written } \\
\text { in the caption }\end{array}$ & Talkative \\
\hline 5 & $\begin{array}{l}\text { Content in the form } \\
\text { of instagramable } \\
\text { photos about hijab } \\
\text { travel, skincare, and } \\
\text { self potraits }\end{array}$ & $\begin{array}{l}\text { Looking for an } \\
\text { interesting place } \\
\text { for a photo session } \\
\text { and doing photo } \\
\text { editing }\end{array}$ & $\begin{array}{l}\text { One place has } \\
\text { different spots for } \\
\text { various personal, } \\
\text { endorsement, and } \\
\text { campaign photos. }\end{array}$ \\
\hline \multirow{2}{*}{ No } & \multicolumn{3}{|c|}{ Informan 2 : Ghaida Tsurayya } \\
\hline & Front virtual & Middle Virtual & Back Virtual \\
\hline 1 & Hijab Celebrity & $\begin{array}{l}\text { Using Instagram } \\
\text { application }\end{array}$ & 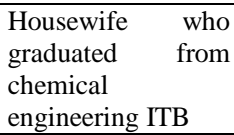 \\
\hline 2 & $\begin{array}{l}\text { Using syar'i and } \\
\text { stylish hijab }\end{array}$ & $\begin{array}{l}\text { Prepare outfit and } \\
\text { hijabs to mix and } \\
\text { match }\end{array}$ & $\begin{array}{l}\text { Appear to be } \\
\text { modest }\end{array}$ \\
\hline 3 & Simple make up & $\begin{array}{l}\text { Use powder and } \\
\text { lipstick }\end{array}$ & Without make up \\
\hline 4 & $\begin{array}{l}\text { Photo captions } \\
\text { contain preaching } \\
\text { calls }\end{array}$ & $\begin{array}{l}\text { Write notes in a } \\
\text { cellphone notepad } \\
\text { to write in photo } \\
\text { captions }\end{array}$ & $\begin{array}{lr}\text { Read al-qur'an } \\
\text { before doing any } \\
\text { activity including } \\
\text { uploading photos / } \\
\text { videos } \\
\text { Instagram }\end{array}$ \\
\hline
\end{tabular}


Table 2. Cont.

\begin{tabular}{|c|c|c|c|}
\hline 5 & $\begin{array}{l}\text { Content in the form } \\
\text { of instagramable } \\
\text { photos about hijab } \\
\text { travel, skincare, and } \\
\text { self-portraits }\end{array}$ & $\begin{array}{l}\text { Looking for an } \\
\text { interesting place } \\
\text { for a photo session } \\
\text { and doing photo } \\
\text { editing }\end{array}$ & $\begin{array}{l}\text { One place has } \\
\text { different spots for } \\
\text { various personal, } \\
\text { endorsement, and } \\
\text { campaign photos }\end{array}$ \\
\hline No & \multicolumn{3}{|c|}{ Informan 3 : Sonya Fatmala } \\
\hline & Front virtual & Middle Virtual & Back Virtual \\
\hline 1 & Hijab celebrity & $\begin{array}{l}\text { Using Instagram } \\
\text { application }\end{array}$ & Entrepreneur \\
\hline 2 & Modest appearance & $\begin{array}{l}\text { Prepare outfit and } \\
\text { hijabs to mix and } \\
\text { match }\end{array}$ & $\begin{array}{l}\text { Using branded } \\
\text { goods }\end{array}$ \\
\hline 3 & Simple make up & $\begin{array}{l}\text { Wear a cushion, } \\
\text { blush, mascara and } \\
\text { lipstick }\end{array}$ & Simple Make up \\
\hline 4 & $\begin{array}{l}\text { Persuasive, concise, } \\
\text { concise and clear } \\
\text { photo captions }\end{array}$ & $\begin{array}{l}\text { Adapting to brand } \\
\text { demands, } \\
\text { endorsers, and their } \\
\text { own desires (for } \\
\text { personal posts) }\end{array}$ & Friendly \\
\hline 5 & $\begin{array}{l}\text { Content in the form } \\
\text { of photos about } \\
\text { parenting, daily } \\
\text { activities, charity, } \\
\text { and self-portraits }\end{array}$ & $\begin{array}{l}\text { Looking for an } \\
\text { interesting place } \\
\text { for a photo session } \\
\text { and doing photo } \\
\text { editing }\end{array}$ & $\begin{array}{l}\text { One place has } \\
\text { different spots for } \\
\text { various personal, } \\
\text { endorsement, and } \\
\text { campaign photos }\end{array}$ \\
\hline \multirow{2}{*}{ No } & \multicolumn{3}{|c|}{ Informan 4 : Asri Ismaya } \\
\hline & Front virtual & Middle Virtual & Back Virtual \\
\hline 1 & Hijab celebrity & $\begin{array}{l}\text { Using Instagram } \\
\text { application }\end{array}$ & Entrepreneur \\
\hline 2 & $\begin{array}{l}\text { Stylist with colorful } \\
\text { colors complete with } \\
\text { clips on the hijab }\end{array}$ & $\begin{array}{l}\text { Prepare outfit and } \\
\text { hijabs to mix and } \\
\text { match }\end{array}$ & $\begin{array}{l}\text { Appear to be } \\
\text { modest }\end{array}$ \\
\hline 3 & $\begin{array}{l}\text { Make up with } \\
\text { "fever" blush on }\end{array}$ & $\begin{array}{lr}\text { Wear } & \text { cushion, } \\
\text { thick } & \text { blush, } \\
\text { mascara, } & \text { and } \\
\text { lipstick } & \end{array}$ & Without make up \\
\hline 4 & Short photo caption & $\begin{array}{l}\text { Spontaneous, } \\
\text { according to mood }\end{array}$ & Talkative \\
\hline 5 & $\begin{array}{l}\text { Content in the form } \\
\text { of photos with } \\
\text { illustrations } \\
\text { graphics } \\
\text { fashion }\end{array}$ & $\begin{array}{l}\text { Find interesting } \\
\text { places for a photo } \\
\text { session, and add } \\
\text { illustrations } \\
\text { graphics and do } \\
\text { photo editing }\end{array}$ & $\begin{array}{l}\text { Often get photos } \\
\text { that do not match } \\
\text { expectations, so } \\
\text { they have to be } \\
\text { repeated }\end{array}$ \\
\hline \multirow{2}{*}{ No } & \multicolumn{3}{|c|}{ Informan 5 : Rissa Stelar } \\
\hline & Front virtual & Middle Virtual & Back Virtual \\
\hline 1 & Hijab celebrity & $\begin{array}{l}\text { Using Instagram } \\
\text { application }\end{array}$ & Former journalist \\
\hline 2 & $\begin{array}{l}\text { Using a plain hijab } \\
\text { in pink, black and } \\
\text { navy }\end{array}$ & $\begin{array}{l}\text { Prepare a plain } \\
\text { hijab }\end{array}$ & $\begin{array}{lll}\text { Prefers } & \text { hijab } \\
\text { without } & \text { motif } \\
\text { (plain) with } & \text { basic } \\
\text { colors } & & \end{array}$ \\
\hline 3 & Full make up & $\begin{array}{l}\text { Use foundation / } \\
\text { cushion, powder, } \\
\text { eyeshadow, } \\
\text { eyeliner, fake } \\
\text { lashes, blush, and } \\
\text { lipstick }\end{array}$ & Simple make up \\
\hline 4 & $\begin{array}{l}\text { Long photo caption } \\
\text { about the lipstick } \\
\text { that he reviewed and } \\
\text { the other interesting } \\
\text { side of the lipstick }\end{array}$ & $\begin{array}{l}\text { Based on } \\
\text { experience or } \\
\text { adjusting to the } \\
\text { demand for lipstick } \\
\text { brands }\end{array}$ & $\begin{array}{l}\text { Person who likes to } \\
\text { tell stories }\end{array}$ \\
\hline 5 & $\begin{array}{l}\text { Content in the form } \\
\text { of photos (lip } \\
\text { photos) and videos }\end{array}$ & $\begin{array}{l}\text { Prepare products, } \\
\text { lighting, and photo } \\
\text { backgrounds }\end{array}$ & $\begin{array}{l}\text { The photo process } \\
\text { to upload to } \\
\text { Instagram takes } 2\end{array}$ \\
\hline
\end{tabular}

\begin{tabular}{|l|l|l|l|}
\hline $\begin{array}{l}\text { about lipstick } \\
\text { products. }\end{array}$ & $\begin{array}{l}\text { to } 3 \text { weeks. The } \\
\text { uploaded content } \\
\text { uses special } \\
\text { software. }\end{array}$ \\
\hline
\end{tabular}

Source: Research result, 2019-2020

The virtual identities they display refer to the self-concept of each key informant. Where there are two main components in the self-concept that will produce self-identity. The two components are self-image and self-esteem [17].

The table above shows the self-image of each key informant through its front stage. Informant Bella Attamimi shows a cool, wise female character, with her expertise in the field of fashion who is always a trendsetter. This character later became Bella Attamimi's own brand on Instagram (Bella's interview, 29 November 2019).

Informant Ghaida Tsurayya shows the character of a religious housewife. This character also carries a brand for Ghaida Tsurayya. Before she created content on Instagram, she already realized this. What characters should appear and how these characters will become her own brand (interview with Ghaida, 18 December 2019).

Informant Sonya Fatmala shows the character of a housewife who has a happy family, is an expert in parenting, and is a generous person. Parenting content is more dominant on Instagram than other content to support its self-image. She created this self-image so that the brand or endorser chose her as a program that represented the brand. Therefore, the content she uploads is paid content from a brand or endorser (interview with Sonya, January 5, 2020).

Informant Asri Ismaya shows a cheerful character through the content she uploads. In the virtual, she also shows a character who is skilled in the field of fashion, her style is even a trendsetter. Her best-known breakthrough is "jepit hijab". The content that she displays is always about fashion with distinctive colorful colors according to her personality (interview with Ismaya, January 10, 2020).

Informant Rissa Stellar shows that she is an expert in a certain field, namely lipstick. She is a trendsetter because of its different content from celebrities with other beauty genres. The content not only shows the side that she is a regular lipstick swatcher, but there is education as well as another side about lipstick. Therefore, she becomes a reference for her followers. So that the "lipstick dictionary" became her brand (interview with Rissa, 17 January 2020).

The self-esteem component refers to self-esteem or how the key informants assess themselves. There are three components in measuring self-esteem, based on global self-esteem, namely overall self-esteem, self-evaluation, and feeling of self-worth. In measuring this self-esteem, key informants provide responses about bad comments and hate comments that appear on their Instagram as a form of key informants showing their self-esteem, as well as emotional feelings regarding their selfesteem (interview with 5 key informants) (see in table 3 ). 
TABLE III. SELF-ESTEEM OF KEY INFORMANTS

\begin{tabular}{|l|l|l|}
\hline \multicolumn{1}{|c|}{ Global self esteem } & \multicolumn{1}{|c|}{ Self-evaluation } & \multicolumn{1}{c|}{$\begin{array}{c}\text { Feeling of self- } \\
\text { worth }\end{array}$} \\
\hline $\begin{array}{l}\text { - Proud to have had } \\
\text { many endorsements }\end{array}$ & $\begin{array}{l}\text { - Do not care about } \\
\text { negative comments on } \\
\text { Instagram. }\end{array}$ & $\begin{array}{l}\text { - Happy to be } \\
\text { known by many } \\
\text { people }\end{array}$ \\
$\begin{array}{l}\text { - Proud to be able to } \\
\text { Instagram }\end{array}$ & $\begin{array}{l}\text { - Be more introspective } \\
\text { with negative } \\
\text { comments that enter } \\
\text { Instagram }\end{array}$ & $\begin{array}{l}\text { - Happy to have } \\
\text { lots of friends }\end{array}$ \\
$\begin{array}{l}\text { - Valuable can be } \\
\text { useful for his followers }\end{array}$ & $\begin{array}{l}\text { - Be wiser in choosing } \\
\text { which content should } \\
\text { be uploaded and not } \\
\text { uploaded to Instagram }\end{array}$ & $\begin{array}{l}\text { - The burden of } \\
\text { endorsement } \\
\text { photo. }\end{array}$ \\
$\begin{array}{l}\text { - Valuable can be a } \\
\text { trendsetter }\end{array}$ & $\begin{array}{l}\text { - Tired of having } \\
\text { to look perfect }\end{array}$ \\
$\begin{array}{l}\text { - Proud and valuable } \\
\text { for being the first } \\
\text { lipstick swatcher in } \\
\text { Indonesia }\end{array}$ & $\begin{array}{l}\text { - Further develop self- } \\
\text { skills in the digital field }\end{array}$ & \begin{tabular}{l} 
- Be ordinary. \\
\hline
\end{tabular}
\end{tabular}

Source: Research result, 2019-2020

From this description, the researcher makes typifications based on the research results of the key informants in the following figure 1 :

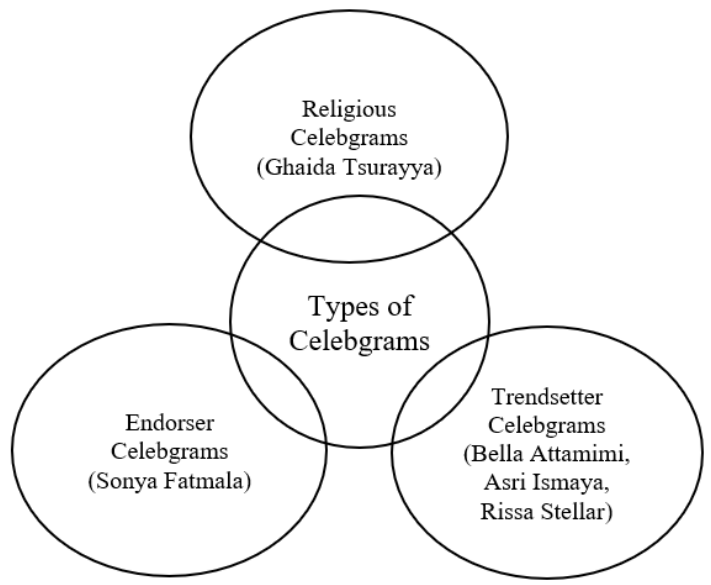

Source: Research result, 2019-2020

Fig. 1. Types of hijab celebrity.

First, the type of religious hijab celebgram. The type shown by informant Ghaida Tsurayya who always applies Islamic values, both in her virtual world and in her daily life (interview with Ghaida, 18 December 2019). Second, the hijab celebrities are the creators of today's trends, namely trendsetter celebgram that are always trendsetting according to their fields. Even the celebgram becomes a reference or inspiration for his followers. Usually, in terms of fashion or make-up, informant Bella Attamimi, informant Asri Ismaya and informant Rissa Stellar are shown. The three key informants created the latest trends in their respective fields. For example, informant Bella Attamimi who created the hijab travel trend. She is a hijab travel trendsetter for hijabers (interview with Bella, 29 November 2019), informant Asri Ismaya who created the "jepit hijab" trend (interview with Asri, 10 January 2020) and informant
Rissa Stellar who created trend lipstick swatches to help women in choosing lipstick (interview with Rissa, 17 January 2020). Third, the endorser celebgram. As the term "endorser" is usually a hijab celebgram of this type, the uploads are dominated by products from a good brand, a brand that is not well known and even a well-known brand that is important to suit him. This type was shown by informant Sonya Fatmala. Uploads on Instagram which are dominated by endorse products and even campaigns from a brand make researchers categorize informants Sonya Fatmala as hijab endorse celebrities (interview with Sonya, January 5, 2020).

\section{CONCLUSION}

In the end, every individual has unlimited freedom to create who they are in the virtual world. The results of this creation represent individuals in playing their roles and interacting on the internet. The choice to reveal her identity honestly with the choice of making a fake identity is a choice that can be taken.

The virtual identity attached to the hijab celebrities in this study is divided into three categories or types including, the type of religious celebgram, endorse, and hijab trendsetter. This category is obtaining through the results of analysis of the real life and virtual life of hijab celebrities, front virtual, middle virtual, and back virtual of hijab celebrities, as well as selfesteem of hijab celebrities. Although these identities do not all have the same as real life conditions, they try to become true self.

\section{ACKNOWLEDGMENT}

Thank you to the Ministry of Research and Technology (Kemenristekdikti Republic of Indonesia) and LLDIKTI Region IV and Institute Research and Community Service of Bandung Islamic University (LPPM UNISBA) for supporting the funding of this research through the Masters Thesis Research Grant.

\section{REFERENCES}

[1] A. Pebria, Selebgram: Jangan Gagal Jadi Selebgram. Yogyakarta: Javapublish, 2018

[2] Al-qur'anulkarim

[3] Y. Hermawati, A. Piyatna, and M. Adji, "Instagram Dan Mitos Kecantikan Perempuan Muslim,” Rika Bhs., 2016.

[4] M. Saifulloh and M.U. Siregar, "Pengungkapan Diri Gofar Hilman Sebagai Influencer Melalui Media Instagram,” J. Pustaka Komun., vol. 2, no. 2, pp. 167-180, 2019.

[5] O.I. Fardiana, "Mitos Kecantikan Perempuan Muslim (Studi Diskursif Dalam Blog Fashion Muslim)," Surabaya Univ. Airlangga, 2014.

[6] N. Arief, "Public Relations in The Era of Artificial Intelligence (Bagaimana Big Data Dan AI Merevolusi Dunia PR)," Bandung: Simbiosa Rekatama Media, 2019.

[7] Sugiyono, Memahami Penelitian Kualitatif. Bandung 40252: AlfabetaBandung, 2013.

[8] P. Prihandini, "Pengalaman Komunikasi Pemakaian Jilbab Fashionable," Commed J. Komun. dan Media, vol. 1, no. 1, pp. 51-68, 2017. 
[9] K. Nisa and R. Rudianto, "Trend Fashion Hijab Terhadap Konsep Diri Hijabers Komunitas Hijab Medan,” J. Interak. J. Ilmu Komun., vol. 1, no. 1, pp. 105-117, 2017.

[10] J.W. Creswell, "Research Design Pendekatan Kualitatif, Kuantitatif, Dan Mixed," Yogyakarta: pustaka pelajar, 2010.

[11] A.M. Putra and A. Febrina, "Fenomena Selebgram Anak: Memahami Motif Orang Tua," J. Aspikom, vol. 3, no. 6, pp. 1093-1108, 2019.

[12] P.Q. Ayun, "Fenomena Remaja Menggunakan Media Sosial Dalam Membentuk Identitas," J. Channel, vol. 3, no. 2, pp. 1-16, 2015.
[13] R. Nasrullah, "Teori Dan Riset Media Siber (Cybermedia): Edisi Pertama," Jakarta Kencana Media Gr., 2014.

[14] T. Widiastuti, "Representasi Identitas Virtual Dalam Konteks Etnografi Di Sosial Media Grindr," J. SIGNAL, vol. 7, no. 1, pp. 82-99, 2019.

[15] R. Nasrullah, "Konstruksi Identitas Muslim Di Media Baru," Komunika J. Dakwah Dan Komun., vol. 5, no. 2, pp. 221-234, 2011.

[16] Morrisan, Teori Komunikasi: Individu hingga Massa. Jakarta: Indonesia: Prenadamedia Group, 2013.

[17] J. Rakhmat, Psikologi Komunikasi. Bandung: Bandung: Remaja Rosdakarya, 2012. 